\title{
Evaluating Early Childhood Educational Program (A Case Study on Public Policy Implementation in Indonesia)
}

\author{
${ }^{1}$ A.Abbas Arby, ${ }^{2}$ Billy Tunas, ${ }^{3}$ Rita Retnowati \\ ${ }^{1}$ Post Graduate Program, Universitas Pakuan Bogor, Indonesia
}

\begin{abstract}
The purpose of this study is to evaluate the effectiveness of the implementation performance program of Early Childhood Education (ECD) in Bogor. The study used a qualitative descriptive approach to evaluate the component of context, input, process and product (CIPP).
\end{abstract}

Data collection is conducted through research interviews, documentation, and observation. To reach the level of credibility and objectivity or particularity, the research applied triangulation techniques. The collection of data and information is obtained from the several Education Office in using four (4) levels of categorization namely: Highly Satisfactory, Satisfactory, Unsatisfactory and Very Unsatisfactory.

The results show that the performance of the program reaches a value of "Unsatisfactory" so that the implementation of the program in the city of Bogor should be followed by a particular treatment in every aspect. Treatment requires every aspect of "sustainable improvement" so that the quality of the implementation of the program in Bogor can achieve a better standard of suitability to meet the demanding needs of the community.

Keywords: Effectiveness, Evaluation, Program Improvement, Sustainable.

\section{INTRODUCTION}

Early childhood education is an essential requirement of each of the nations in the world since the beginning until now. Educational needs of the generation that is still in its infancy are more important for the children as at that time they are biologically and psychologically developed. The importance of early childhood education in the perspective of time is more necessary because children at that age are very promising in the long run with all the potential creative they have. The creative potential of early childhood - the default learners who will be an active movement is strongly influenced by any treatment obtained in education during the age of 5-6 in the first year at school. Father of Indonesian education Ki Hajar Dewantara viewed that children should be seen as a central figure in the world of education.

Programs for early childhood education (ECD) is a node that needs to be researched and examined, then measured through an evaluation based on its components namely: context, input, process, and product. Program evaluation is an evaluation instrument that is "necessary" to observe the condition. Through research it is also expected in the next period of strategic plans of the city of Bogor, issue of early childhood education becomes a priority in development. In educational realm, especially early childhood education is a very big opportunity for the growth of a child's world.

To meet the demands of contemporary educational world in Indonesia, the Ministerial Regulation No. 58 of 2009, which has been transformed into Regulation No. 137 of 2014 on Standards for Early Childhood Education policy has set about eight (8) standard of educational quality to be achieved by the manager and the organizers of the Early Childhood Education Program.

Program Evaluation Policy of Early Childhood Education is a necessary to be studied carefully for the implementation of the program as likely the present day are not implemented effectively, program management performed is inadequate and is not optimal, then the research is intended to undertake a study thorough and integrative evaluation to obtain information relevant to the implementation of early childhood programs in the city of Bogor, Indonesia followed by improvement efforts if deemed necessary. Implementation of Early Childhood Education Program still needs further and deeper 
attention because the conditions that appear on the surface does not seem like it should be.

Through research conducted methodically and systematically to the Early Childhood Education program, I is expected eventually result analysis can provide the solution and a way out to some of problems that exist in the community, especially related to early childhood education in the city of Bogor, Indonesia.

With reference to the focus of the problem, the main objectives of the study are to:

1. Obtain information on the effectiveness of the performance of a program, and measure the achievement of results from the implementation of early childhood education program, which is set out in the strategic plan of the Department of Education in the city of Bogor.

2. Obtain information on availability of plans, strategies, availability of resources, the use of facilities and infrastructures, as well as costs used effectively and efficiently.

3. Measure the mechanism of management and implementation of programs, stage performance or procedures, as well as the implementation of the program based on the strategic plan prepared by the educational department.

4. Evaluate the results of the implementation of the early childhood program, and gain accuracy transition value and benefits in accordance with desired goals and objectives of the program.

\section{Literature REVIEW}

Limitation of the word "evaluation" according Wirawan (2012) is a research evaluation to collect, analyze, and present useful information about the object of evaluation, assessing and comparing the target object of evaluation with evaluation indicators, and the results are used to make decisions about the object being evaluated.

According to Davidson (2005), quoting Scriven, "evaluation is the systematic determination of the quality, value, or importance of something" that evaluation is a determination made in a systematic assessment of the quality, value, or importance of something to obtain comparative values of a certain size standards explicitly or implicitly that has dimensions of criteria on certain aspects of a program.

Vendung Evert (2009) says that the Evaluation is the process of determining the merit, worth, and value of things. In these expressions, it can be interpreted that the evaluation is a process for setting benefits, price, and the value of something.

Birkland (2001) in relation to public policy emplementasi revealed that: "Evaluation is the process of determining whether and to what extent a program is achieving some benefit explicitly or implicitly.

According to. Stufflebeam and Chris Coryn (2014): "evaluation is the systematic assessment of the worth or merit of an object". Evaluation is an act of assessment in a systematic way to achieve the value and benefits of a particular object. Thus, the activities of the evaluation of a program can be understood as an attempt to get the value and benefit to the desired target in the program. Stufflebeam and Coryn added that the evaluation activities related to the achievement of values such as effectiveness, efficiency, utility, finance, safety, legality, and so forth. Such activities should use the structured and tiered procedures.

In the book entitled Evaluating Public Relations, Watson and Paul Noble (2007) said that: "the practice of evaluation involves the systematic collection of information about the activities, characteristics, and outcomes of programs, personnel, and products for specific used by people to reduce uncertainties, improve effectiveness, and the make decisions regarding to what are reviewed on those programs, personnel, or products doing and affecting. The emphasis of the evaluation was to carry out the improvement of the effectiveness of program performance. The evaluation is the systematic measurement activities against a program, to get the facts that can be the raw material for the making of the decision, and seek to obtain the values of the results or benefits of the product of the program.

Newcomer, Harry P. Hatry, Joseph S. Wholey, (2010) states that: "the program is a set of resources and activities directed toward one or more common goals, typically under the direction of the single manager or management team." A program is a set of activities that have a specific purpose, and the activities of different kinds of resources that leads to one or more specific objectives. A program has been arranged perfectly by a strategic plan provided leads to certain goals are usually run by a manager or it can also be done by a program management team. 
According to Jones, (2002) understanding of the work program is an activity that has obtained approval to achieve the goal. The program has certain characteristics that can help researchers to identify whether an activity can be considered as a program or not. Implementation of a program tends to require a number of executive staff in the field with the task to run programs already available. A program typically has its own budget, which means that the evaluation of a program can also be identified through the available budget. The program also has its own style that can run effectively so as to obtain public recognition.

Langbein and Claire L. Felbinger (2006) in a book entitled Public Program Evaluation: A Statistical Guide say that: "programs are ongoing services or activities ... that are intended to have ongoing, long-term effects, ... or goals , include the provision of social and other public services and the implementation of regulations designed to affect the behavior of individuals, business, or organization. "

Measures to evaluate the program are considered to anticipate the number of climatic changes in society. In other terms related to the evaluation program terms, Langbein and Claire L. Felbinger (2006) says: "program evaluation is the application of empirical social science research methods to process of judging the effectiveness of public policies, programs, or projects, as well as their management and implementation, for decision making purposes. "

Madaus, and Daniel L. Stufflebeam (2002) provides a definition of the evaluation of the program as: "program evaluation means a study designed and conducted to assist some audience to assess an object's merit and worth." Evaluating of the program is more emphasized on planning and implementation in measuring or assessing a performance of a program. The measurement or assessment seeks to get the benefits and values that can meet the demands of the interested parties, for the benefit of the service provider and the community.

When evaluating programs, this research is associated with professional standards used in Standard for Educational Evaluation to build a contribution for the improvement in the areas of learning, teaching, administration, health, and in general to improve quality of life.

\section{Data Collection}

Although many models of evaluation of the program used as a reference for the study the implementation of early childhood programs, this study chose to use the model CIPP approach which includes the evaluation and assessment of the Context, Input, Process, and Product. Selection of program evaluation model is due to systematic and thorough the alignment of and it has a strong relevance to the model criteria initiated by Dunn (2000), involving six (6) certain criteria that should have been achieved in the implementation of a program of choice. Model CIPP is a concept evaluation of Public Policy Program implementation i based on the systematic integrative mechanisms. The advantages of this model that it can reveal an object of research to be more objective and at the same time thoroughly since this model makes the object of research traced comprehensively and simultaneously follow the stages that continuously so that the "treatment" evaluation can be carried out repeatedly. On this basis, the study can make a proposition "hypothesis" that are relevant to the implementation of the evaluation that the model as selection program evaluation initiated by Stufflebeam (2014) - Model CIPP - has a high degree of accuracy to "observe" the implementation of programs for early childhood education in the city of Bogor, Indonesia.

The following matrix displays the patterns of relational activity formative - summative evaluation relevant to the CIPP model approach.

Figure1. Relevance components in the standard CIPP Formative - Summative Evaluation (Stufflebeam and Coryn, 2014)

\begin{tabular}{|c|c|c|c|c|}
\hline Evaluation & Context & Input & Process & Product \\
\hline $\begin{array}{l}\text { Formative } \\
\text { Evaluation } \\
\text { Questioning the } \\
\text { planning of a } \\
\text { prospective } \\
\text { program }\end{array}$ & $\begin{array}{l}\text { The evaluation } \\
\text { should provide an } \\
\text { answer to the first } \\
\text { question that } \\
\text { arises: What } \\
\text { needs to be } \\
\text { done? }\end{array}$ & $\begin{array}{l}\text { The evaluation is } \\
\text { done on the } \\
\text { performance of the } \\
\text { sub-components } \\
\text { supporting the } \\
\text { implementation of a } \\
\text { selected program. }\end{array}$ & $\begin{array}{l}\text { Evaluation is } \\
\text { questioning how } \\
\text { to supervise and } \\
\text { monitor } \\
\text { irregularities that } \\
\text { will happen }\end{array}$ & $\begin{array}{l}\text { Evaluation of the } \\
\text { final results of } \\
\text { what is being } \\
\text { planned at the } \\
\text { time to come. }\end{array}$ \\
\hline
\end{tabular}


A. Abbas Arby et al.

\begin{tabular}{|c|c|c|c|c|}
\hline $\begin{array}{l}\text { Summative } \\
\text { Evaluation } \\
\text { Questioning the } \\
\text { activities at the } \\
\text { end of the } \\
\text { execution of a } \\
\text { program not only } \\
\text { retrospectively } \\
\text { but also overall }\end{array}$ & $\begin{array}{l}\text { Finding a } \\
\text { significant } \\
\text { difference from } \\
\text { what the needs, } \\
\text { goals and } \\
\text { objectives of a } \\
\text { program }\end{array}$ & $\begin{array}{l}\text { Find advantages and } \\
\text { disadvantages in } \\
\text { supporting resources } \\
\text { to the performance of } \\
\text { activity on selected } \\
\text { program }\end{array}$ & $\begin{array}{l}\text { The evaluation of } \\
\text { a program must } \\
\text { be monitored co- } \\
\text { ntinuously to } \\
\text { reduce undesired } \\
\text { deviations }\end{array}$ & $\begin{array}{l}\text { The evaluation of } \\
\text { the final results are } \\
\text { to find quality and } \\
\text { overall impact, the } \\
\text { negative side } \\
\text { effects or any other } \\
\text { positive results } \\
\text { beyond } \\
\text { expectations. }\end{array}$ \\
\hline
\end{tabular}

This study took place in the city of Bogor, Indonesia. Most sources of primary data are obtained from the Education Office of Bogor, and secondary data information are collected from Bogor City community who are concerned with early childhood education, such as the Association of Early Childhood and Kindergarten, Teacher Association throughout the city of Bogor. To complete the collection of accumulated information about the implementation of public policy programs of early childhood, researchers used data and population statistics from the early age groups Statistical Center Bureau.

The duration of the research activities is carried out for approximately six (6) months, starting from December 2014 to May 2015. The stages of the research activities are organized into work plan implementation of continuous research of the preparation, implementation, data collection, interviews, data analysis, preparation of research results, and writing.

\section{RESULT AND DisCUSSION}

The results of evaluation studies on the implementation of Early Childhood Education Program (ECEP) in Bogor City Department of Education reveal various facts on the values of the findings obtained simultaneously on the object of study. Achievement of the research findings of program evaluation form: the findings of the evaluation of field observation target of the study, the findings of an evaluation of the forms of documentation are available on the object of research, and the findings of research evaluation interviews with relevant parties competent interested in educational programs of Early Childhood Education Program (ECEP) in the city of Bogor. Disclosure of the findings of the evaluation of the program conducted through the components (C) context, (I) Input, (P) processes, and $(\mathrm{P})$ product that subsequently use excerpts model "CIPP" is described below:

Table1. The Result of Observation based on CIPP Model

\begin{tabular}{|r|l|l|l|c|}
\hline NO. & COMPONENTS & EVALUATIONS & EVALUATION RESULTS & SCORE (OUT OF 4) \\
\hline 1 & CONTEXT & BASE & LESS RELEVANT & 2 \\
\hline & & NEEED & LESS RELEVANT & 2 \\
\hline & & OBJECTIVES & LESS RELEVANT & 1 \\
\hline & & & & 2 \\
\hline & INPUT & PLANNING & NOT ACCURATE & 2 \\
\hline & & STRATEGY & LESS ACCURATE & 2 \\
\hline & & PROCEDURE & LESS ACCURATE & 2 \\
\hline & & HUMAN RECOURCES & LESS ACCURATE & 2 \\
\hline & & INFRASTRUCTURES & LESS ACCURATE & 2 \\
\hline 3 & & BUDGETS & LESS ACCURATE & 2 \\
\hline & & & & 2 \\
\hline & & COORDINATION & LESS EFFECTIVE & \\
\hline & & IMPLEMENTATION & LESS EFFECTIVE & 2 \\
\hline 4 & PRODUCT & SUPERVISION & LESS EFFECTIVE & 2 \\
\hline & & & & \\
\hline
\end{tabular}

\section{Conclusion}

Implementation of programs for early childhood education program in Bogor City is less effective for implementing the program does not meet the basic demands of the suitability of the policy program set out in Regulation No. 58 Year 2009 which has been converted into a ministerial regulation No. 137 of 2014 on early childhood education standards. Identification of needs and planning of programs associated with the component input presented is less precise in aims and objectives. At the level of the process, the implementation of the program would be conducted less effective for achieving 
quality standards of service to the community, especially to early age children. The service quality standards give effect to the direct component of the product that appears on the surface in the realization of the achievement of value that less than satisfactory in implementation of the program. Achievement of the value and benefits of such program also eventually has no good implications for the benefit of public education, especially for the future of children in the city of Bogor.

\section{REFERENCES}

Birkland, Thomas A., an Introduction to Policy Process: Theories, Concepts, and Models of Public Policy, Armonk, New York: M.E. Sharpe, 2001

Davidson, E. Jane, Evaluation Methodology Basics, London: Sage Publications, 2005

Dunn, William N., Pengantar Analisis Kebijakan Publik, (terjemahan edisi ke 2), Yogyakarta: Gajah Mada University Press, 2000

Jones, Charles O., Pengantar Kebijakan Publik, Terjemahan oleh Ricky Istamto, Jakarta: Raja Grafindo Persada, 2002

Langbein, Laura I., and Felbinger, Claire L., Public Program Evaluation: A Statistical Guide, Armonk, New York: M.E. Sharpe, Inc., 2006

Madaus, G.F., and Stufflebeam, Daniel L., Evaluation Models: Viewpoints on Educational and Human Services Evaluation, $2^{\text {nd }}$ Ed., Dordrectht: Kluwer Academic Publishers, 2002

Newcomer, Kathryn E., Hatry, Harry P., Wholey, Joseph S., Planning and Design Useful Evaluation, Handbook of Practical Program Evaluation, $3^{\text {rd }}$ Edition, Sanfranscisco: Jossey-Bass, 2010

Stufflebeam, Daniel L., Chris L.S. Coryn., Evaluation Theory, Models, and Applications, $2^{\text {nd }}$ Ed., Jossey-Bass, A Wiley Brand, San Fransisco, 2014

Vendung, Evert., Public Policy and Program Evaluation., USA:Transaction Publishers, Fourth Paperback Printing, 2009

Watson, Tom., and Noble, Paul.,Evaluating Public Relations, London, UK: Kogan Page, 2007

Wirawan, Evaluasi: Teori, Model, Standard, Aplikasi, dan Profesi, Depok: Rajagrafindo Persada, 2012 